\title{
3'-R-Spiro[cycloalkyl-1(2), (hetaryl-3(4), 6'-[1,2,4]triazino[2,3-c] quinazoline]-2'(7'H)-2-ones as a perspective class of compounds with actoprotective activity
}

\author{
0. S. Kolomoets, O. Yu. Voskoboynik, I. S. Nosulenko, 0. V. Kryvoshey, \\ A. I. Avramenko, G. G. Berest, S. I. Kovalenko \\ Zaporizhzhia State Medical University, Ukraine
}

Quinazolines and their derivatives are a perspective class of compounds with versatile biological activities. Their representatives are used in medical practice as sleeping, diuretic, antimicrobial and antitumor drugs. Continuing our search of perspective compounds with actprotective activity among azolo-(azino-)[c]quinazoline derivatives it was decided to combine the mentioned above heterocyclic system with carbocyclic or heterocyclic fragments in one molecule. Moreover, an affinity to melanocortin-4, nociceptin (NOP), adenosine, GABA and glutamine receptors among spiropiperidines, spiropiperidinoquinazolines, spiropiperidi notriazoloquinazolines, spiroindolinoquinazolines and others was found and as a rule they exhibit neuroprotective, neurotrophic, anti-inflammatory and other actions.

Aim. The aim of the present work was the primary screening of actoprotective activity among novel 3'-R-spiro [cycloalkyl-1(2), (hetaryl-3(4), 6')-[1,2,4]triazino[2,3-c]quinazoline]-2'(7'H)-2-ones, estimating of antiradical activity as the possible mechanism of actoprotection and the evaluation of perspectivity of further profound researches for high-active compounds.

Materials and methods. Actprotective activity of perspective and unknown 3'-R-spiro[cycloalkyl-1(2), (hetaryl-3(4), 6'-[1,2,4] triazino[2,3-c]quinazoline]-2' $\left(7^{\prime} H\right)$-2-ones was studied using the swimming test at the temperature $24-26^{\circ} \mathrm{C}$ (normothermia) with additional load ( $10 \%$ from the weight of experimental animal). The experiment was carried out on white Wistar rats and "Mildronate" was used as a reference drug.

Results and discussion. It was found, that most of the tested compounds being intragastrically administrated increased the duration of experimental animals swimming in dose of $50 \mathrm{mg} / \mathrm{kg}$ in conditions of normothermia. Also, we found a number of high active compounds $(1.6,1.11,1.12,1.18,1,19,1.25)$, that were superior to the reference drug "Mildronate" by the level of actoprotection on $13.2-47.8 \%$. It was shown that there is no reliable dependence between actoprotective and antiradical activities among 3'-R-spiro[cycloalkyl-1(2), (hetaryl-3(4), 6'-[1,2,4]triazino[2,3-c]quinazoline]-2'(7'H)-2-ones. The analysis of "structure - activity" correlation showed that critical factors in revealing of high actprotective action is not only the size and nature of spirocycle of position 6 , but also a substituent in position 3 of triazino[2,3-c]quinazoline system. The most active compounds 1.6, 1.11, 1.12, 1.18, 1.19 and 1.25 were recommended for further pharmacological studies.

\section{3'-R-Спіро[цикмоалкіл-1(2), (гетарил-3(4), 6'-[1,2,4]триазино[2,3-с]хіназолін]- 2'(7'H)-2-они - перспективний клас сполук з актопротекторною активністю}

О. С. Коломоєць, О. Ю. Воскобойнік, І. С. Носуленко, О. В. Кривошей, А. І. Авраменко, Г. Г. Берест, С. І. Коваленко

Хіназоліни та їхні похідні - перспективний клас сполук із різноманітною біологічною активністю, представники якого застосовуються в медичній практиці як снодійні, діуретичні, антимікробні, протипухлинні засоби. У продовження попередніх досліджень щодо пошуку перспективних сполук з актопротекторною активністю серед похідних азоло-(азино-)[c] хіназолінів цікавим було поєднання в одній молекулі карбоциклічних і гетероциклічних фррагментів. Ба більше, що серед спіропіперидинів, спіропіперидинохіназолінів, спіропіперидинотриазолохіназолінів, спіроіндолінохіназолінів виявлена аффінність до меланокортину-4, ноцицептинових (NOP), аденозинових, ГАМК- і глутамінових рецепторів, і вони, як правило, проявляють нейропротекторну, нейротрофрічну, протизапальну та інші дії.

Мета роботи - первинний скринінг 3'-R-спіро[циклоалкіл-1(2), (гетарил-3(4), 6')-[1,2,4]триазино[2,3-c]хіназолін]-2'(7'H)-2онів на актопротекторну активність, вивчення антирадикальної дії як вірогідного механізму актопротекції та оцінювання перспективності високоактивних сполук для дальшого поглибленого дослідження.

Матеріали та методи. Актопротекторну активність для перспективних і невідомих 3'-R-спіро[циклоалкіл-1(2), (гетарил-3(4), 6')-[1,2,4]триазино[2,3-с]хіназолін]-2'(7'H)-2-онів вивчено за тестом плавальної проби при температурі 24-26 $\mathrm{C}$ (нормотермія) з додатковим навантаженням (10\% від маси тіла експериментальних тварин). Дослідження здійснили на білих щурах лінії Вістар, як референс-препарат використаний «Мілдронат».

Результати. Встановили, що більшість протестованих сполук при внутрішньошлунковому введенні у дозі 50 мг/кг збільшують тривалість плавання експериментальних тварин в умовах нормотермії. Виявлений ряд високоактивних сполук $(1.6,1.11,1.12,1.18,1.19,1.25)$, що за рівнем актопротекторної активності перевищують референс-препарат «Мілдронат» на 13,2-47,8\%. Показано, що вірогідної залежності між актопротекторною та антирадикальною активністю серед 3'-R-спіро[циклоалкіл-1(2), (гетарил-3(4), 6')-[1,2,4]триазино[2,3-c]хіназолін]-2'(7'H)-2-онів немає. Аналіз взаємозв'язку «структура - активність» показав: критичними фракторами у прояві високої актопротекторної дії $є$ не тільки розмір і природа спіроциклу положення 6, а також замісник положення 3 триазино[2,3-с]хіназолінової системи. Найактивніші сполуки 1.6, 1.11, 1.12, 1.18, 1.19 та 1.25 рекомендовані для подальших фрармакологічних досліджень.

Key words: 3'-R-spiro[cycloalkyl1(2), (hetaryl-3(4), 6'-1,2,4]triazino [2,3-c]quinazoline]2'(7'H)-2-ones, swimming test, normothermia, actoprotective and antiradical activities.

Zaporozhye medical journal 2017; 19 (2), 227-232 DOI: 10.14739/2310-1210. 2017.2.95748

E-mail: a.yu.voskoboynik@ gmail.com

Ключові слова: 3'-R-спіро [циклоалкіл-1(2), (гетарил-3(4), 6'-[1,2,4]триазино[2,3-с]хіназоАін]-2' (7'H)-2-они, плавальний тест, нормотермія, актопротекторна та антирадикальна активність.

Запорізький медичний журнал. - 2017. T. 19, № 2(101). C. 227-232 
Ключевые слова:

3'-R-спиро

[циклоалкил-1(2), (гетария-3(4), 6'-

$[1,2,4]$ триазино

[2,3-с]хиназолин]-

2'(7'H)-2-оны,

физическая

выносливость,

плавательный тест, нормотермия,

актопротекторная

и антирадикальная

активность.

Запорожский медицинский журнал. - 2017. -

T. 19, № 2(101). C. 227-232

\title{
3'-R-Спиро[циклоалкил-1(2), (гетарил-3(4), 6'-[1,2,4]триазино[2,3-с]хиназолин]-2'(7'H)-2- оны - перспективный киасс соединений с актопротекторной активностью
}

\author{
А. С. Коломоец, А. Ю. Воскобойник, И. С. Носуленко, О. В. Кривошей, А. И. Авраменко, \\ Г. Г. Берест, С. И. Коваленко
}

Хиназолины и их производные - перспективный класс соединений с разнообразной биологической активностью, представители которого используются в медицинской практике в качестве снотворных, диуретических, противомикробных, противоопухолевых препаратов. В продолжение предыдущих исследований по поиску перспективных соединений с актопротекторной активностью среди производных азоло-(азино-)[c]хиназолинов интересным было сочетание в одной молекуле карбоциклических и гетероциклических фрагментов. Тем более, что среди спиропиперидинов, спиропиперидинохиназолинов, спиропиперидинотриазолохиназолинов, спироиндолинохиназолинов и других обнаружена аффинность к мелакортину-4, ноцицептиновим, аденозиновим, ГАМК- и глютаминовым рецепторам, и они, как правило, проявляют нейропротекторное, нейротрофическое, противовоспалительное и другие действия.

Цель работы - первичный скрининг 3'-R-спиро[циклоалкил-1(2), (гетарил-3(4), 6')-[1,2,4]триазино[2,3-c]хиназолин]-2'(7'H)-2-онов на актопротекторную активность, изучение антирадикального действия как вероятного механизма проявления актопротекции и потенциальных высокоактивных соединений для дальнейшего углублённого изучения.

Материалы и методы. Актопротекторная активность перспективных и неизвестных 3'-R-спиро[циклоалкил-1(2), (гетарил-3(4), 6')-[1,2,4]триазино[2,3-с]хиназолин]-2'(7'H)-2-онов была изучена с использованием теста плавательной пробы при температуре $24-26^{\circ} \mathrm{C}$ (нормотермия) с дополнительной нагрузкой (10\% от массы тела экспериментальных животных). Исследования проведены на белых крысах линии Вистар, в качестве ресреренс-препарата использован «Милдронат».

Результаты. Установлено, что большинство протестированных соединений при внутрижелудочном введении в дозе 50 мг/кг увеличивают продолжительность плавания экспериментальных животных в условиях нормотермии. Обнаружен ряд высокоэффективных соединений $(1.6,1.11,1.12,1.18,1.19,1.25)$, которые по уровню актопротекторной активности превышают референс-препарат «Милдронат» на 13,2-47,8\%. Показано, что достоверной зависимости между актопротекторной и антирадикальной активностью среди 3'-R-спиро[циклоалкил-1(2), (гетарил-3(4), 6')-[1,2,4]триазино[2,3-c] хиназолин]-2'(7'H)-2-онов не существует. Анализ взаимосвязи «структура - активность» показал, что критическими факторами в проявлении высокого актопротекторного действия являются не только размер и природа спироцикла положения 6, а также заместитель положения 3 триазино[2,3-c]хиназолиновой системы. Наиболее активные соединения 1.6, 1.11, 1.12, 1.18, 1.19 и 1.25 рекомендованы для дальнейших фрармакологических исследований.

Quinazolines and its derivatives as perspective objects of structural modification and functionalization aimed to search for novel bioactive substances attract attention of scientists more and more [1-4]. Since their first synthesis in 1869, identifying the main quinazoline alkaloids and creation of drugs with diverse biological activity only 150 years have passed [5]. During this period, compounds with diverse pharmacological action were found and a large number of original drugs, which are used in medical practice as sleeping, diuretics, antimicrobial, anticancer drugs were created [2,6]. Recently, due to the molecular and biochemical mechanisms and the development of medical chemistry, condensed quinazoline analogues have been studied intensively. Thus, compounds with anticonvulsant, analgesic, anti-inflammatory, autotropic, antioxidant and other types of activity have been found among mentioned above class of compounds $[2-4,7]$.

Continuing our search [8-12] of perspective compounds with actprotective activity among azolo-(azino-)[c]quinazoline derivatives we decided to combine the mentioned above heterocyclic system with carbocyclic or heterocyclic fragments in one molecule. Moreover, an affinity to melanocortin-4, nociceptin (NOP), adenosine, GABA and glutamine receptors was found and as a rule they exhibit neuroprotective, neurotrophic, anti-inflammatory and other actions [13-17].

The aim of the present work was the primary screening of actoprotective activity among novel 3'-R-spiro [cycloalkyl-1(2), (hetaryl-3(4), 6')-[1,2,4]triazino[2,3-c]quinazoline]$2^{\prime}\left(7^{\prime} H\right)$-2-ones, estimating of antiradical activity as the possible action mechanism and the evaluation of perspectivity of further profound researches for high-active compounds.

\section{Materials and methods}

An unknown 3'-R-spiro[cycloalkyl-1(2), (hetaryl-3(4), 6'[1,2,4]triazino[2,3-c]quinazoline]-2'(7'H)-2-ones (1.1-1.33) were chosen as the objects of present study. These compounds were synthesized by known method [18] at the department of organic and bioorganic chemistry at Zaporizhzhia state medical university (the Head of the Department, Prof. Kovalenko S. I.). The basic structure of these compounds is shown in Fig. 1.

Actoprotective activity. The actoprotective and antiradical activities were studied at the department of pharmacognosy, pharmacology and botany of Zaporizhzhia State Medical University (the Head of the department Associate professor, Dr.hab. Trzhetsynskiy). An experimental studies were performed on white Wistar rats, weighing 160-200 g, aged 3.5 months, that were obtained from the nursery PE "Biomodelservis". The duration of quarantine was 2 weeks. During this experiment the animals were examined two times a day. They were kept on a standard diet with natural day and night changes and free access to water and feed. The temperature was maintained in the range of $19-25^{\circ} \mathrm{C}$ and the relative moisture was $50-70 \%$. The temperature and moisture were recorded daily. Ventilation regime was 15 volumes of air per an hour. The animals were kept in standard cages $(400 \times 320 \times 160 \mathrm{~mm})$ in groups of 6 rats. The diet was feed grains, bread, vegetables (beets, carrots) $[19,20]$. All experimental procedures were carried out according to the "Regulations on using of animals in biomedical research" [20,21].

Having been quarantine and individually fuchsine marked animals were selected and divided into groups 
consisting of 6 male rats in the conditions of absence of external signs of disease and homogeneity of groups of their weight $( \pm 15 \%)$. The weight of each laboratory animal was determined before the beginning of the experiment. The animals immediately drowned or hung on the water surface were excluded from experiment. The experiment included the following stages: the first swimming to the complete exhaustion; set of the experimental groups according to the time of the first swimming through the way of tandem selection; second swimming to exhaustion (5 minutes after the first); intragastric administration of the studied compounds at dose $50 \mathrm{mg} / \mathrm{kg}$; third swimming (after 1 hour) after administration of the compound.

Swimming test was carried out with an additional load, that was attached near to base of the tail $(10 \%$ from the rat weight) with previously boiled water (to remove air bubbles) at the temperature $24-26{ }^{\circ} \mathrm{C}$ (normothermia) $[8,9,11,12]$. The swimming time was fixed by the signs of full exhaustion that was revealed by the way of giving up from further swimming, lowering down the bottom and inability to swim out for more than 10 seconds. The rats were swimming separately in square transparent glass vessel (size $180 \times 60 \times 60 \mathrm{~cm}$, height $40 \mathrm{~cm}$ ). This methodology allowed to evaluate the physical activity of the laboratory rats in mixed physical activity implemented by aerobic-anaerobic system.

Intragastric administration of substance was carried out using noninvasive probe in the form of water suspension with adding of tween- 80 in 60 minutes before testing at dose $50 \mathrm{mg} / \mathrm{kg}$ was. The equivalent volume of distilled water with tween- 80 was administrated to the control animal group in the similar way. The effectiveness of the investigated compounds was compared with the control group and the action of the reference drug. The Mildronate was used at dose $50 \mathrm{mg} / \mathrm{kg}$ as a reference drug considering described activity of mentioned above compound [22], previously reported protocols for actoprotective activity estimating [23] and own experimental data. Adynamic which is relatively to the control (DRC) in \% according to the next equation was calculated:

$$
\mathrm{DRC}=\frac{\text { Ave. swimming (compound) }- \text { Ave. swimming (control) }}{\text { Ave. swimming (control) }} \times 100
$$

Statistical data processing was carried out by using the standard package of statistical program analysis processing results, version Microsoft Office Excel 2003, Statistica ${ }^{\circledR}$ for Windows 6.0 (StatSoft Inc., № AXXR712D833214FAN5). Parameters of arithmetic mean (M) and standard error and representativeness of the arithmetic mean $(m)$ for each investigated compound were calculated. At the level of significance $p<0.05$ the null hypotheses was rejected when the statistical hypotheses was checked.

Antiradical activity. Research of antiradical activity in vitro was based on the interaction of synthesized compounds with 2.2-diphenyl-1-picrylhydrazile (DPPH) [24,25]. DPPH is a stable free radical and its alcohol solutions are colored in intense purple color $\left(\lambda_{\max }=517 \mathrm{~nm}\right)$. DPPH interacted with compounds that are able to bind with free radicals yields products, which are yellow colored and does not absorb the light at specified above wavelengths.

Research methodology. $2 \mathrm{ml}$ of $1 \mathrm{mM}$ solution of compound in DMSO was mixed with $2 \mathrm{ml}$ of $0.1 \mathrm{mM} \mathrm{DPPH}$ methanol solution and it was incubated for 30 minutes at the temperature of $25^{\circ} \mathrm{C}$ and optical density $\left(A_{d}\right)$ was measured $[24,25]$. The optical density of $2 \mathrm{ml}$ of $0.1 \mathrm{mM}$ DPPH solution in $2 \mathrm{ml}$ of methanol $\left(A_{D P P H}\right)$ was determined simultaneously. Antiradical activity (ARA) was calculated by the next formula: $A R A \%=\left(A_{D P P H}-A_{d}\right) / A_{D P P H} \times 100 \%$. In the case of a negative meaning ARA in $\%$ was estimated like 0 . Weighing reagents and synthesized compounds were conducted on electronic scales "ANG200C" and the optical density was measured by a spectrophotometer ULAB108UV.<smiles>[R]c1nn2c(nc1=O)-c1ccccc1NC21CCC([R])C1</smiles><smiles></smiles>

$1.12,1.13$<smiles>[R]c1nn2c(nc1=O)-c1ccccc1NC21CCCC1[X]</smiles><smiles>[X]CCC12CCN1n1nc([R])c(=O)nc1-c1cc([R])ccc1N2</smiles><smiles>[R]c1ccc2c(c1)C1(Nc3ccccc3-c3nc(=O)c([R])nn31)C(=O)N2</smiles><smiles>[R]c1nn2c(nc1=O)-c1ccccc1NC21C(=O)N(CC(=O)Nc2ccc(OC)cc2)c2ccccc21</smiles>

Fig. 1. The structures of tested 3'-R-spiro[cycloalkyl-1(2), (hetaryl-3(4), 6'-[1,2,4]triazino[2,3-c]quinazoline]-2'(7'H)-2-ones (1.1-1.33). 


\section{Results and discussion}

The given data (Table 1, 2) showed, that previous administration of Mildronate and synthesized compounds to rats led to the increasing of physical endurance in comparison with the control in the conditions of normothermia. It should be noted that the determining factor in the revealing of actoprotective activity was the heterocyclic fragment of molecule $([1,2,4]$ triazino[2,3-c]quinazoline) as well as structural variety of substituents of the position 3 and 6 . Thus, the introduction of 3'-phenyl-spiro[cyclobutyl-1, 6')-[1,2,4]triazino[2,3-c]quinazoline]-2'(7'H)-2-one (1.1) to rats led to unreliable increasing of swimming time of rats in comparison with the control group (Table 1). The modification of the molecule by introducing of other substituents (4-fluorophenyl-(1.2), 4-methoxyphenyl-(1.3)) in position 3 of heterocycle did not lead to the significant increasing of activity. However, the compounds 1.1-1.3 exhibit the significant antiradical activity by inhibiting DPPH-radical on $40-50 \%$ amid of moderate actoprotective activity. The compound 1.3 has the highest activity among the named compounds and increases the duration of swimming at $13.2 \%$ in the presence of antiradical activity and competes with Mildronate (Table 1). Introduction of cyclopentyl substituent (1.4) instead of cyclobutyl (compound 1.2) in position 6 ' led to the loss of the antiradical, as well as actoprotective activities. Whereas, further modification of $[1,2,4]$ triazino[2,3-c]quinazoline system through the introduction to the position 6 of 4-tert-butylhexyl substituent $(1.5,1.6)$

Table 1. Antiradical and actoprotective activities of 3'-R-spiro[cycloalkyl-1(2), 6'-[1,2,4]triazino[2,3-c]quinazoline]-2'(7'H)-2-ones (1.1-1.11)

\begin{tabular}{|c|c|c|c|c|c|c|c|}
\hline № & Code & $\mathbf{R}$ & $\mathbf{R}_{1}$ & $\mathrm{n}$ & Average swimming time, sec & Actoprotective action, $\%$ & ARA $\%$, (conc $\left..1 \times 10^{-3}\right)$ \\
\hline 1 & Ascorbic acid & - & - & - & - & - & 68,21 \\
\hline 2 & Control group & - & - & - & $159 \pm 30$ & 0 & - \\
\hline 3 & Mildronate & - & - & - & $180 \pm 39^{*}$ & 13.21 & - \\
\hline 4 & $1.1 \mathrm{KK}-43$ & $\mathrm{Ph}$ & $\mathrm{H}$ & 0 & $163 \pm 17$ & 2.52 & 45.39 \\
\hline 5 & $1.2 \mathrm{KK}-44$ & $4-\mathrm{FC}_{6} \mathrm{H}_{4}$ & $\mathrm{H}$ & 0 & $150 \pm 29$ & -5.66 & 49.95 \\
\hline 6 & $1.3 \mathrm{KK}-45$ & 4- $\mathrm{MeOC}_{6} \mathrm{H}_{4}$ & $\mathrm{H}$ & 0 & $180 \pm 57$ & 13.21 & 36.96 \\
\hline 8 & $1.5 \mathrm{AV}-334$ & $\mathrm{Me}$ & 4-tert- $\mathrm{C}_{4} \mathrm{H}_{9}$ & 2 & $187 \pm 39^{*}$ & 17.61 & 29.94 \\
\hline 9 & $1.6 \mathrm{AV}-341$ & $\mathrm{Ph}$ & 4-tert- $\mathrm{C}_{4} \mathrm{H}_{9}$ & 2 & $201 \pm 42^{*}$ & 26.41 & 47.86 \\
\hline 10 & $1.7 \mathrm{KK}-50$ & $\mathrm{Me}$ & $\mathrm{H}$ & 3 & $137 \pm 12^{\star \#}$ & -13.84 & -0.36 \\
\hline 11 & $1.8 \mathrm{KK}-48$ & $4-\mathrm{FC}_{6} \mathrm{H}_{4}$ & $\mathrm{H}$ & 3 & $158 \pm 12$ & -0.63 & -4.75 \\
\hline 12 & $1.9 \mathrm{KK}-49$ & 4- $\mathrm{MeOC}_{6} \mathrm{H}_{4}$ & $\mathrm{H}$ & 3 & $178 \pm 39$ & 11.95 & 1.63 \\
\hline 13 & $1.10 \mathrm{KK}-24$ & $4-\mathrm{FC}_{6} \mathrm{H}_{4}$ & - & - & $183 \pm 12^{\#}$ & 15.09 & -8.60 \\
\hline 14 & $1.11 \mathrm{KK}-25$ & 4- $\mathrm{MeOC}_{6} \mathrm{H}_{4}$ & - & - & $216 \pm 89$ & 35.85 & 2.64 \\
\hline
\end{tabular}

*: $p \leq 0.05$ in relation to the control group of rats; **: $p \leq 0.05$ in relation to group of rats received Mildronate.

Table 2. Antiradical and actoprotective activities of 3'-R-spiro[hetaryl-1(3,4), 6'-[1,2,4]triazino[2,3-c]quinazoline]-2'(7'H)-2-ones (1.1-1.33)

\begin{tabular}{|c|c|c|c|c|c|c|c|}
\hline № & Code & $\mathbf{R}$ & $x$ & $\mathbf{R}_{1}$ & Average swimming time, sec & Actoprotective action, $\%$ & ARA $\%$, (conc. $\left.1 \times 10^{-3}\right)$ \\
\hline 1 & Ascorbic acid & - & - & - & - & - & 68.21 \\
\hline 2 & Control group & - & - & - & $159 \pm 30$ & 0 & - \\
\hline 3 & Mildronate & - & - & - & $180 \pm 39^{*}$ & 13.21 & - \\
\hline 4 & $1.12 \mathrm{AV}-729$ & $\mathrm{Ph}$ & $S$ & - & $197 \pm 27^{*}$ & 23.90 & 1.35 \\
\hline 5 & $1.13 \mathrm{KK}-34$ & $4-\mathrm{FC}_{6} \mathrm{H}_{4}$ & $\mathrm{SO}_{2}$ & - & $177 \pm 39$ & 11.32 & 4.85 \\
\hline 6 & $1.14 \mathrm{AV}-754$ & $\mathrm{Ph}$ & 0 & - & $169 \pm 50$ & 6.29 & -1.26 \\
\hline 7 & $1.15 \mathrm{KK}-90$ & $\mathrm{Me}$ & $S$ & - & $194 \pm 75$ & 22.01 & 8.53 \\
\hline 8 & $1.16 \mathrm{KK}-89$ & $\mathrm{Ph}$ & $S$ & - & $129 \pm 21^{\#}$ & -18.87 & -8.53 \\
\hline 9 & 1.17 KK-91 & $4-\mathrm{FC}_{6} \mathrm{H}_{4}$ & $S$ & - & $142 \pm 40$ & -10.69 & -7.62 \\
\hline 10 & $1.18 \mathrm{AV}-344$ & $\mathrm{Ph}$ & $\mathrm{N}-\mathrm{Me}$ & - & $242 \pm 65^{\text {*\# }}$ & 52.20 & 0.97 \\
\hline 11 & $1.19 \mathrm{AV}-356$ & $4-\mathrm{EtC}_{6} \mathrm{H}_{4}$ & $\mathrm{~N}-\mathrm{Me}$ & - & $210 \pm 58^{*}$ & 32.08 & 1.26 \\
\hline 12 & $1.20 \mathrm{AV}-360$ & $4-\mathrm{PrC}_{6} \mathrm{H}_{4}$ & $\mathrm{~N}-\mathrm{Me}$ & - & $183 \pm 12^{\#}$ & 15.09 & -0.15 \\
\hline 13 & 1.21 AV-357 & 3.4- $\mathrm{Me}_{2} \mathrm{C}_{6} \mathrm{H}_{3}$ & $\mathrm{~N}-\mathrm{Me}$ & - & $190 \pm 33^{*}$ & 19.50 & 2.36 \\
\hline 14 & 1.22 AV-347 & $4-\mathrm{FC}_{6} \mathrm{H}_{4}$ & $\mathrm{~N}-\mathrm{Me}$ & - & $170 \pm 31$ & 6.92 & 1.23 \\
\hline 16 & 1.24 AV-359 & 4-EtOC ${ }_{6} \mathrm{H}_{4}$ & $\mathrm{~N}-\mathrm{Me}$ & - & $120 \pm 30^{\#}$ & -24.53 & 2.52 \\
\hline 17 & 1.25 AV-358 & 4- $\mathrm{FC}_{6} \mathrm{H}_{4}$ & $\mathrm{~N}-\mathrm{Me}$ & $\mathrm{Br}$ & $256 \pm 76^{\star \#}$ & 61.01 & 1.95 \\
\hline 18 & 1.26 AV- 498 & $\mathrm{Me}$ & - & - & $160.5 \pm 57$ & 0.94 & 51.56 \\
\hline 19 & $1.27 \mathrm{AV}-497$ & $\mathrm{Ph}$ & - & - & $153 \pm 12^{*}$ & -3.77 & 42.16 \\
\hline 20 & $1.28 \mathrm{AV}-517$ & 4-iso- $\mathrm{PrC}_{6} \mathrm{H}_{4}$ & - & - & $168 \pm 30$ & 5.66 & 29.13 \\
\hline 21 & 1.29 AV-514 & $4-\mathrm{FC}_{6} \mathrm{H}_{4}$ & - & - & $172 \pm 32$ & 8.18 & 35.98 \\
\hline 22 & 1.30 AV-515 & thienil-2 & - & - & $151 \pm 23$ & -5.03 & 37.21 \\
\hline 23 & 1.31 KK-59 & 4- $\mathrm{FC}_{6} \mathrm{H}_{4}$ & - & $\mathrm{Br}$ & $190 \pm 33^{\text {*\# }}$ & 19.50 & 66.42 \\
\hline 24 & 1.32 KK-60 & 4- $\mathrm{MeOC}_{6} \mathrm{H}_{4}$ & - & $\mathrm{Br}$ & $188 \pm 33^{*}$ & 18.24 & 66.01 \\
\hline 25 & $1.33 \mathrm{KK}-40$ & $\mathrm{Ph}$ & - & - & $186 \pm 40^{*}$ & 16.98 & -6.17 \\
\hline
\end{tabular}

$*: p \leq 0.05$ in relation to the control group of rats; ${ }^{*}: p \leq 0.05$ in relation to group of rats received Mildronate. 
leads to a significant increasing of actoprotective activity in the presence of moderate antiradical activity (Table 1). It is important, that substituent of position 3 influences to the actoprotective activity of the compounds $1.5,1.6$ in case if the phenyl substituent (1.6) the actoprotective activity is higher comparing to Mildronate $13.2 \%$.

Expansion of spirocycle in position 6 ' of $[1,2,4]$ triazino[2,3-c]quinazolines $(1.5,1.6)$ to the cycloheptyl $(1.7-1.9)$ leads to loss of not only actoprotective activity, but also antiradical activity. Only compound 1.9 with 4-methoxyphenyl substituent shows the moderate actoprotective activity among these compounds. Whereas, the introduction of bicyclic fragment (compounds 1.10,1.11) to the position 6 of $[1,2,4]$ triazino[2,3-c]quinazoline system positively influences the actoprotective activity. Thus, in the absence of antiradical activity mentioned above compounds increase the average swimming time of experimental animals at $15.09-35.85 \%$ respectively in comparison with the control group.

The following modification of molecule was directed to the introduction of hetaryl fragment to the position 6 of $[1,2,4]$ triazino[2,3-c]quinazoline system and aimed to the enhancing of the actoprotective activity (Table 2). Thus, it was established that the introduction of tetrahydrothiopyrane fragment (1.12) to the position 6 led to the increasing of swimming time of rats and resulted the increasing of the activity at $10.7 \%$ in comparison with a control group. The modification of the compound 1.12 by oxidation of Sulfur in substituent of position 6 to the corresponding sulfones (1.13) reduces the duration of animal swimming by 2 times. Repositioning of Sulfur in tetrahydrothiopyrane cycle (compounds 1.15-1.17), replacing it to tetrahydropyrane cycle (1.14) and the modification of the substituent at position 3 of heterocycle led to the loss $(1.14,1.16,1.17)$ of biological activity or maintenance it on the same level (1.15). 3'-R-1-methylspiro[piperidine-4,6'-[1,2,4]triazino[2,3-c] quinazoline]-2'(7'H)-ones (1.18-1.24) were more interesting in biological scope and it is important that their actoprotective activity depends on the nature of the substituent in position 3. Thus, compounds with phenyl (1.18), 4-ethylphenyl (1.19), 4-iso-propylphenyl (1.20) and 3,4-dimethylphenyl (1.21) moieties exceed Mildronat's activity on $1.88-38.99 \%$. The compounds with 4-fluorophenyl (1.22), 4-methoxyphenyl (1.23) and 4-ethoxyphenyl (1.24) substituents were proved to be less active. However, the additional introduction of bromine into the compound 1.22 in position 10 of $[1,2,4]$ triazino[2,3-c]quinazoline fragment led to a significant increasing of activity, which exceeds Mildronate's at $47.8 \%$. It should be noted, that the compounds 1.12-1.25 don't reveal the antiradical activity (Table 2). However, the introduction of indoline fragment to the position 6 of triazinoquinazoline cycle (1.26-1.32) led to the high antiradical activity, which is close to ascorbic acid in some cases (Table 2). However, compounds 1.26-1.30 with different substituents in position 3 don't show $(1.27,1.30)$ or have a poor $(1.26,1.28,1.29)$ actoprotective activity. It should be noted that the introduction of bromine in position 5 of indoline moiety of the molecule $(1.31,1.32)$ led to the increasing of actoprotective activity on $10-11 \%$. Further modification of compound 1.27 by introduction of the acetanilide substituent doesn't increase the swimming time of rats.

Thus, the search of actoprotective activity among unknown 3'-R-spiro[cycloalkyl-1(2), (hetaryl-3(4), 6')-[1,2,4]
triazino[2,3-c]quinazoline]-2'(7'H)-2-ones revealed a number of high active compounds $(1.6,1.11,1.12,1.18,1.19$ and $1.25)$, which were recommended for further pharmacological research. A reliable dependence between the actoprotective and the antiradical activities of the compounds wasn't found and probably their mechanism of action is different.

\section{Conclusions}

The actoprotective activity of unknown 3'-R-spiro[cycloalkyl-1(2), (hetaryl-3(4), 6')-[1,2,4]triazino[2,3-c]-quinazoline]$2^{\prime}\left(7^{\prime} H\right)$-2-ones was established for the first time. It was shown that among 3'-R-spiro[cycloalkyl-1(2), (hetaryl-3(4), $\left.6^{\prime}\right)$-[1,2,4]triazino[2,3-c]-quinazoline]-2'(7'H)-2-ones there wasn't a reliable dependence between the actoprotective and the antiradical activities. Analysis "structure - activity" relationships showed that the critical factors in determining the high actoprotective action is not only the size and the nature of spiro-fragment of the position 6, but also the substituent in position 3 of triazino[2.3-c]quinazoline cycle. The compounds $1.6,1.11,1.12,1.18,1.19$ and 1.25 were recommended for further studies considering there higher (13.2-47.8\%) actoprotective activity comparing to "Mildronate" .

\section{References}

[1] Connolly, D. J., Cusack, D., O'Sullivan, T., \& Guiry, P. J. (2005) Synthesis of quinazolinones and quinazolines. Tetrahydron, 61, 10153-10202. http://dx.doi.org/10.1016/j.tet.2005.07.010.

[2] SudhakarBabu, K., Prabhakar, V., Ravindranath, L. K., Latha, J., \& Nagamaddaiah, H. K. (2015) Quinazoline Derivatives and its Biological Significance. International Journal of Current Trends in Pharmaceutical Research, 3(5), 997-1010.

[3] Imtiaz, Khan, Aliya, Ibrar, Naeem, Abbas, \& Aamer, Saeed (2014) Recent advances in the structural library of functionalized quinazolineand quinazolinone scaffolds: Synthetic approaches and multifarious applications. European Journal of Medicinal Chemistry, 76, 193-244. doi: 10.1016/j.ejmech.2014.02.005.

[4] Ugale, V. G., \& Bari, S. B. (2014) Quinazolines: new horizons in anticonvulsant therapy. European Journal of Medical Chemistry, 80, 447-501. doi: 10.1016/j.ejmech.2014.04.072.

[5] Michael, J. P. (2008) Quinoline, quinazoline and acridone alkaloids. Nat Prod Rep., 25(1), 166-187. doi: 10.1039/b612168n.

[6] https://www.drugbank.ca/unearth/q?approved=1\&button=\&c= score\&d=down\&illicit=1\&investigational=1\&nutraceutical=1\&que$r y=$ quinazolin\&searcher $=$ drugs\&utf $8=\% E 2 \% 9 \mathrm{C} \% 93 \&$ vet_approved $=1 \&$ withdrawn $=1$.

[7] Borchardt, A. J., Beauregard, C., Cook, T., Davis, R. L., Gamache, D. A \& Yanni, J. M. (patentee) (2010) Pat. US 2010/0120741 A. Heterocyclic inhibitors of histamine receptors for the treatment of disease. Kalypsys Inc. Alcon Research Ltd (US); Filed: 10.09.2009; Posted: 13.05.2010.

[8] Stepaniuk, H. I., Toziuk, O. Yu., Kovalenko, S. I., Chornoivan, N. I., Antypenko, L. M., Antypenko, O. M. (patentee) (2013) Patent Ukrayiny №79229 MPK (2013.01)A61K 31/00. 5-R-tio-tetrazolo[1,5-s]khinazoliny, shcho pidvyshchuiut fizychnu vytryvalist orhanizmu [Ukraine Patent № 79229 МПК (2013.01) A61K 31/00. 5-R-thiotetrazolo[1,5-c]quinazolines which increase the physical endurance.]. Bulleten, 7. [in Ukrainian].

[9] Stepaniuk, H. I., Berest, H. H., Marynich, L. I., Chornoivan, N. I., Pashinska, O. S., Saienko, A. V., et al. (patentee) (2011) Patent Ukrayiny №96186 MPK (2006.01) S07D 253/06, S07D 253/10,S07D 253/10,S07D 239/72. Soli (3-R-2-okso-2N-[1,2,4]tryazyno[2,3-s]khinazolin-6-il-sulfanil) alkilkarbonovykh kyslot, shcho proiavliaiut protyishemichnu, nootropnu, protysudomnu ta aktoprotektornu aktyvnist [Ukraine Patent №96186 МПК (2006.01) C07D 253/06, C07D 253/10,C07D 253/10,C07D 239/72. 3-R-2-oxo-2H-[1,2,4]triazino[2,3-c]quinazolin-6-yl-sulfanyl)alkylcarboxylic acids which reveals antiischemic, nootropic, anticonvulsant an actoprotective activity]. Bulleten, 19. [in Ukrainian].

[10] Tozyuk, E. Yu., \& Stepanyuk, G. I. (2014) Porivnialna otsinka vplyvu natriiu 2-(tetrazolo[1,5-s]khinazolin-5-iltio)atsetatu ta bemitylu na protses vidnovlennia fizychnoi pratsezdatnosti shchuriv [Comparative evaluation of sodium 2-(tetrazol[1,5-c]quinazolin-5-ylthio)-acetate and bemityl effects on the recovery process of physical working capacity of rats]. Farmakolohiia ta likarska toksykolohiia, 2(38), 59-63. [in Ukrainian]. 
[11] Pochelova, E. V., Stepanjuk, G. I., Denysiuk, O. N., \& Chornoivan, N. G. (2013) Kharakterystyka aktoprotektornoi dii pokhidnykh (3-R-okso-2N-[1,2,4]tryazyno[2,3-s]khinazolin-6-il)karbonovykh kyslot za riznykh temperaturnykh rezhymiv [Characteristics of actoprotective actions of (3-R-oxo-2H-[1,2,4]-triazino- [2,2-c]-quinazolin-6-yl) carboxylic acid derivatives at different temperature conditions]. Farmakolohiia ta likarska toksykolohiia, 3(34), 54-57. [in Ukrainian].

[12] Kolomoets, O. S., Nosulenko, I. S., Voskoboynik, O. Yu., Berest, G. G. Kovalenko, S. I., \& Trzhetsinsky, S. D. (2016) Aktoprotektorna aktyvnis 6-monozamishchenykh 3-R-6,7-dyhidro-2H-[1,2,4]tryazyno[2,3-c]khinazolin-2-oniv [Actoprotective activity of 6-monosubstituted 3-R-6,7-dihydro-2H-[1,2,4]triazino-[2,3-c]quinazoline-2-ones]. Current issues in pharmacy and medicine: science and practice, 2(12), 80-82. doi: 10.14739/2409-2932.2016.3.77996. [in Ukrainian].

[13] Kholodniak, S. V., Shabelnyk, K. P., Kovalenko, S. I., Voskoboinik, O. Yu., Bielenichev, I. F., Serheieva, T. Yu., \& Okovytyi, S. I. (patentee) (2015) Patent Ukrainy na korysnu model №103314 (UA), MPK 2015.01, A61K 31/00. Zamishcheni 2-alkil-(tsykloalkil-, aralkil-, aryl-, hetaryl-)6H-spiro[indol-3,5-[1,2,4]tryazolo[1,5-c]khinazolin]-2(1H)-ony, shcho proiavliaiut protysudomnu diiu [Ukraine Patent №103314 (UA), МПК 2015.01, A61K 31/00.Substituted2'-alkyl-(cycloalkyl -, aralkyl-, aryl-, heteryl -)-6' $H$-spiro[indole]-3,5'-[1,2,4]triazolo[1,5-c]quinazolin]-2(1H)ones, revealsanticonvulsantactivity, App. 16.06.2015; Pub. 10.12.2015] Biulleten, 23. [in Ukrainian].

[14] Mustazza, C., Borioni, A., Sestili, I., Sbraccia, M., Rodomonte, A., Ferretti, R., \& Del Giudice, M. R. (2006) Synthesis and evaluation as NOP-ligands of some spiro[piperidine-4,2'(1'H)-quinazolin]-4'(3'H)-ones and spiro[piperidine-4,5'(6'H)-[1,2,4]triazolo[1,5-c]quinazolines]. Chem Pharm. Bull., 54, 611-622. doi: 10.1002/chin.20064515.

[15] Bakshi, R. K., Dellureficio, J. P., Dobbelaar, P. H. et al. (patentee) (2007) Pat. WO 2007/047496 A2. Acylated spiropiperidine derivativesasmelanocortin-4 receptor modulators; Merck\&CO, INC. (US); Filed: 18.10.2006 Posted: 26.04.2007.

[16] Sharma, V., Kumar, P., \& Pathaka, D. (2010) Biological Importance of the Indole Nucleus in Recent Years: A Comprehensive Review. J. Heterocyclic Chem, 47, 491-502. doi: 10.1002/jhet.349.

[17] Pandeya, S. N., Smitha, S., Jyoti, M., \& Sridhar, S. K. (2005) Biological activities of isatin and its derivatives. Acta Pharm, 55, 27-46.

[18] Voskoboinik, O. Yu., Kolomoets, O. S., \& Kovalenko, S. I. (patentee). (2015) Patent Ukrainy na vynakhid №111245, S07D 253/06, C07D 253/10, C07D 239/72, C07D 2487/04. 6-Mono- ta 6,6-dyzamishcheni 3-R-8-R3-9-R4-10-R5-11-R6-6,7-dyhidro-2H-[1,2,4]tryazyno[2,3-c]khinazolin-2-ony [Ukraine Patent №111245, C07D 253/06, C07D 253/10, C07D 239/72, C07D 2487/04. Mono- and disubstituted 3-R-8-R3-9-R410-R5-11-R6-6,7-dihydro-2H-[1,2,4]triazino[2,3-c]quinazolin-2-ones]. Biulleten, 23. [in Ukrainian]

[19] Kozhemiakin, Yu. M., Khromov, O. S., \& Filonenko, M. A. (2002) Naukovo-metodychni rekomendatsii z utrymannia laboratornyk tvaryn ta roboty z nymy [Methodical recommendations for keeping and breeding of laboratory animals and working with them]. Kyiv: Avitsenna. [in Ukrainian].

[20] Nakaz Ministerstva okhorony zdorovia «Poriadok provedennia dok linichnoho vyvchennia likarskykh zasobiv ta ekspertyzy materialiv doklinichnoho vyvchennia likarskykh zasobiv» vid 14.12.2009 r. №944 [Rules for conducting of preclinical study of drugs and expertise of material of preclinical study of drugs from December 14, 2009. №944]. [in Ukrainian].

[21] (1986) European convention for the protection of vertebrate animal used for experimental and other scientific purposes. Strasbourg.

[22] Lukyanchuk,V. D., \& Simonova, I. V. (2015) Aktoprotektory: farmakolohiia ta farmakoterapiia [Actoprotectors: pharmacology and pharmacotherapy]. Farmakolohiia ta likarska toksykolohiia, 2(43), 14-26. [in Ukrainian].

[23] Kornienko, V. I., Shikova, V. V., Samura, B. A., Romanenko, N. I., \& Rak, T. N. (2012) Vliyanie ammonievykh solej N-(3-metil-7-acetilmetilksantinil)-8-N-zameshchennykh piperaziniya na vynoslivost' krys k fizicheskim nagruzkam [Infl uence of ammonium salts of $\mathrm{N}$-(3-methyl-7-acethylmethylxanthinil)-8- $\mathrm{N}$ - of piperazine on rats endurance to the physical loadings]. Problemy ekolohichnoi ta medychnoi henetyky $i$ klinichnoi imunolohii, 6, 385-391. [in Russian].

[24] Kedare, S. B., \& Singh, R. P. (2011) Genesis and development of DPPH method of antioxidant assay. J Food Sci Technol, 48, 412-422. doi: 10.1007/s13197-011-0251-1.

[25] Sharma, O. P., \& Bhat, T. K. (2009) DPPH antioxidant assay revisited. Food Chemistry, 113, 1202-1205. http://dx.doi.org/10.1016/j.foodchem.2008.08.008.

\section{Information about authors:}

Kolomoets O. S., Aspirant, Department of Organic and Bioorganic Chemistry, Zaporizhzhia State Medical University, Ukraine.
Voskoboynik O. Yu., Ph.D., Associate professor, the Department of Organic and Bioorganic Chemistry, Zaporizhzhia State Medical University, Ukraine.

Nosulenko I. S., Ph.D., Teaching Assistant, the Department of Pharmacognosy, Pharmacology and Botany, Zaporizhzhia State Medical University, Ukraine.

Kryvoshey O. V., Ph.D., Associate Professor, the Department of Pharmaceutical Chemistry, Zaporizhzhia State Medical University, Ukraine.

Avramenko A. I., Ph.D., Associate Professor, the Department of Physical and colloidal chemistry, Zaporizhzhia State Medical University, Ukraine.

Berest G. G., Ph.D., Associate Professor, the Department of Pharmacognosy, Pharmaceutical Chemistry and Technology, Zaporizhzhia State Medical University, Ukraine.

KovalenkoS. I., Professor, Dr.hab., Head of the Department of Organic and Bioorganic Chemistry, Zaporizhzhia State Medical University, Ukraine.

\section{Відомості про авторів:}

Коломоєць О. С., аспірант каф. органічної та біоорганічної хімії, Запорізький державний медичний університет, Україна. Воскобойнік О. Ю., канА. фарм. наук, доцент каф. органічної та біоорганічної хімії, Запорізький державний меАичний університет, Україна.

Носуленко І. С., канА. фарм. наук, асистент каф. фармакогнозії, фармакології та ботаніки, Запорізький Аержавний медичний університет, Україна.

Кривошей О. В., канд. фарм. наук, Аоцент каф. фармацевтичної хімії, Запорізький державний медичний університет, Україна. Авраменко А. І., канА. фарм. наук, Аоцент каф. фізичної та колоїдної хімії, Запорізький Аержавний меАичний університет, Україна.

Берест Г. Г., канА. фарм. наук, Аоцент каф. фармакогнозії, фармацевтичної хімії і технології, Запорізький державний медичний університет, Україна.

Коваленко С. І., А-р фарм. наук, професор, зав. каф. органічної та біоорганічної хімії, Запорізький державний меАичний університет, Україна.

\section{Сведения об авторах:}

Коломоец А. С., аспирант каф. органической и биоорганической химии, Запорожский госуАарственный меАицинский университет, Украина.

Воскобойник А. Ю., канА. фарм. наук, Аоцент каф. органической и биоорганической химии, Запорожский государственный медицинский университет, Украина.

Носуленко И. С., канА. фарм. наук, ассистент каф. фармакогнозии, фармакологии и ботаники, Запорожский государственный медицинский университет, Украина. Кривошей О. В., канА. фарм. наук, Аоцент каф. фармацевтической химии, Запорожский государственный медицинский университет, Украина.

Авраменко А. И., канА. фарм. наук, Аоцент каф. физической и коммоиАной химии, Запорожский госуАарственный медицинский университет, Украина.

Берест Г. Г., канА. фарм. наук, Аоцент каф. фармакогнозии, фармацевтической химии и технологии, Запорожский государственный медицинский университет, Украина. Коваленко С. И., А-р фарм. наук, профессор, зав. каф. органической и биоорганической химии, Запорожский государственный меАицинский университет, Украина.

Конфлікт інтересів: віАсутній.

Conflicts of Interest: authors have no conflict of interest to declare.

Надійшло Ао редакції / Received: 14.12.2016

Після Аоопрацювання / Revised: 19.12.2016 Прийнято Ао Аруку / Accepted: 23.12.2016 